\title{
Description of Red Cell Indices in Buskers in Yogyakarta City
}

\section{Gambaran Indeks Eritrosit Pada Anak Jalanan Di Kota Yogyakarta}

Hieronymus Rayi Prasetya*, Titah Dewi Rahadian

\begin{abstract}
The transportation sector has proven to be one of the causes of lead pollution in the air. Lead pollution is a result of vehicle fuel use. Lead is a metal that is very dangerous because it can accumulate in the body resulting in reduced production of erythrocytes and erythrocyte morphological abnormalities. Buskers have a risk of red cell Indices abnormalities due to exposure to vehicle exhaust gas every day. Buskers in the city of Yogyakarta carry out activities (busking) every day around trafficlight so that it will increase the risk of respiratory poisoning. The study was conducted by giving questionnaires to 32 respondents and the red cell Indices examination was performed using a hematology analyzer. The results showed that the average value of red cell Indices based on sex, age, duration of work, alcohol and cigarette consumption habits were still within normal limits (normocytic normochromic). There are no red cell Indices abnormalities (size and color) in buskers in Yogayakarta City
\end{abstract}

Keywords: red cell Indices, buskers, erythrocyte abnormalities

\section{Intisari}

Sektor transportasi terbukti menjadi salah satu penyebab pencemaran timbal di udara. Pencemaran Timbal merupakan akibat dari penggunaan bahan bakar kendaraan. Timbal merupakan metal yang sangat berbahaya karena dapat terakumulasi dalam tubuh sehingga mengakibatkan menurunya produksi eritrosit dan kelainan morfologi eritrosit. Anak jalanan memiliki resiko kelainan indeks eritrosit akibat terpapar gas buang kendaraan setiap hari. Anak jalanan yang berada di kota Yogyakarta melakukan aktifitasnya (mengamen) setiap hari di sekitar trafficlight sehingga akan meningkatkan resiko keracunan timbal melalui pernafasan. Penelitian dilakukan dengan memberikan kuisioner pada 32 responden dan pemeriksaan indeks eritrosit dilakukan menggunakan hematology analyzer. Hasil penelitian menunjukan rata-rata nilai indeks eritrosit anak jalanan berdasarkan jenis kelamin, usia, lama bekerja, kebiasaan konsumsi alkohol dan rokok masih berada dalam batas normal (normositik normokromik). Tidak terdapat kelainan indeks

Afiliasi Penulis

STIKes Guna Bangsa Yogyakarta

Korespondensi kepada

H.R. Prasetya

rayi.prasetya@gmail.com eritrosit (ukuran dan warna eritrosit) pada anak jalanan di Kota Yogayakarta

Kata Kunci : Indeks eritrosit, Anak Jalanan, kelainan eritrosit 


\section{Pendahuluan}

Timbal sering juga disebut dengan timah hitam $(\mathrm{Pb}$; lead). Timbal merupakan metal yang sangat berbahaya bagi kesehatan manusia yang berlangsung seumur hidup karena timbal berakumulasi dalam tubuh manusia. Dalam kasus paparan polusi timbal dalam dosis rendah sekalipun ternyata dapat menimbulkan gangguan pada tubuh tanpa menunjukkan gejala klinik [1].

Di Indonesia keracunan timbal diperkirakan berasal dari berbagai sumber seperti bensin bertimbal, cat, sayuran, pupuk dan lain-lain. Meskipun pemerintah sudah menetapkan bensin bebas timbal sejak Juli 2001, masih ditemukan bensin bertimbal di Palembang, Ambon dan Sorong, dan belum ada peraturan nilai ambang batas penggunaan timbal pada berbagai produk konsumen di Indonesia. Timbal (Pb) dari kendaraan bermotor berasal dari hasil pembakaran bahan tambahan (aditive) $\mathrm{Pb}$ pada kendaraan berbahan bakar bensin yang akan menghasilkan emisi $\mathrm{Pb}$ in organik. $\mathrm{Pb}$ dalam bentuk senyawa alkyl-pb digunakan sebagai campuran bensin yang berfungsi untuk meningkatkan bilangan oktan bahan bakar. Logam berat $\mathrm{Pb}$ yang bercampur dengan bahan bakar dan oli, melalui proses di dalam mesin, menghasilkan logam berat $\mathrm{Pb}$ yang akan keluar melalui knalpot bersama dengan gas buang lainnya [2].

Timbal mempunyai berbagai efek pada sel, peningkatan kadar timbal darah dapat mengganggu eritropoiesis. Timbal terikat pada enzim, dapat mengubah dan menghilangkan efek enzim. Timbal menghambat enzim asam $\delta$ aminolevulinat dehidrase dan ferrokelatase, sehingga enzim asam $\delta$-aminolevulinat dehidrase (ALAS) tidak dapat mengubah porfobilinogen akibatnya besi tidak dapat memasuki siklus protoporfi rin. Perkursor heme, erythrocyte protophorphyrin yang digantikan menjadi zinc protophorphyrin, menjadi meningkat dan pembentukan heme menurun $[3,4]$.

Efek keracunan timbal akan berpengaruh pada hasil indeks eritrosit. Indeks eritrosit merupakan batasan untuk ukuran dan isi hemoglobin eritrosit. Indeks eritrosit ini digunakan dalam mengklasifikasi anemia dan untuk membantu mendiagnosis penyebab anemia. Pemeriksaan indeks eritrosit terdiri dari Volume sel rerata (MCV), hemoglobin sel rerata $(\mathrm{MCH})$, dan konsentrasi hemoglobin sel rerata $(\mathrm{MCHC})$ yang dihitung dari hematokrit (PCV), kadar hemoglobin dan hitung sel darah merah [5].

Anak jalanan memiliki resiko kelainan darah akibat terpapar gas buang kendaraan setiap hari. Anak jalanan yang berada di kota Yogyakarta melakukan aktifitasnya (mengamen) setiap hari di sekitar trafficlight. Aktifitas tersebut yang dilakukan di pinggir jalan raya akan meningkatkan resiko keracunan timbal melalui pernafasan.

\section{Metode}

Survei anak jalanan dilakukan pada bulan Maret-Septermber 2018 pada kawasan trafficlight di 14 Kecamatan yang berada di Kota Yogyakarta. Responden anak jalanan (pengamen) yang diperoleh sebanyak 32 sampel. Responden tersebut diberikan kuisioner untuk mengetahui karakteristik responden. Sampel darah responden diambil sejumlah 3 cc yang ditampung menggunakan tabung vakum EDTA dan diperiksa indeks eritrosit menggunakan hematology analyzer.

\section{Hasil \& Pembahasan}

Survei responden pada 14 Kecamatan yang dilakukan di Kota Yogyakarta didapatkan 32 orang anak jalanan yang bersedia menjadi responden penelitian. Hasil pemeriksaan yang indeks eritrosit yang dilakukan didapatkan hasil seperti pada tabel 1. Pemeriksaan Indeks Eritrosit terdiri dari MCV (Mean Corpuscular Volume), $\mathrm{MCH}$ (Mean Corpuscular Hemoglobin), dan MCHC (Mean Corpuscular Hemoglobin Concentration). MCV berfungsi menunjukkan ukuran eritrosit, $\mathrm{MCH}$ dan MCHC menunjukkan warna eritrosit. Indeks eritrosit merupakan tes penyaring yang dikerjakan pada tahap awal kasus anemia untuk mengetahui jenis anemia berdasarkan morfologi eritrosit [6]. Rentang normal yang digunakan (sesuai dengan hematology analyzer yang digunakan) adalah MCV 76-96 Fl, MCH 27-32 pg, MCHC 30-35 g/dl.

Berdasarkan nilai MCV pada Tabel 1, dapat diketahui $100 \%$ anak jalanan tidak mengalami kelainan ukuran eritrosit (normositik). Berdasarkan 
Tabel 1 | Hasil Pemeriksaan Indeks eritrosit

\begin{tabular}{lcccccc}
\multirow{2}{*}{ Parameter } & \multicolumn{2}{c}{ Rendah } & \multicolumn{2}{c}{ Normal } & \multicolumn{2}{c}{ Tinggi } \\
\cline { 2 - 7 } & $\mathrm{N}$ & $\%$ & $\mathrm{~N}$ & $\%$ & $\mathrm{~N}$ & $\%$ \\
\hline $\mathrm{MCV}(\mathrm{Fl})$ & 0 & 0,0 & 32 & 100,0 & 0 & 0,0 \\
$\mathrm{MCH}(\mathrm{pg})$ & 2 & 6,3 & 30 & 93,8 & 0 & 0,0 \\
$\mathrm{MCHC}(\mathrm{g} / \mathrm{dl})$ & 0 & 0,0 & 26 & 81,3 & 6 & 18,8 \\
\hline
\end{tabular}

nilai $\mathrm{MCH}$, terdapat 6,3\% anak jalanan memiliki nilai $\mathrm{MCH}$ kurang dari normal yang menunjukan kelainan hipokromik. Berdasarkan nilai MCHC, terdapat $18,8 \%$ anak jalan memiliki nilai $\mathrm{MCHC}$ yang tinggi (hiperkromik). Hasil pada Tabel 1 memiliki nilai $\mathrm{MCH}$ dan $\mathrm{MCHC}$ yang berlawanan (hipokromik dan hiperkromik), hal tersebut diakibatkan karena hasil pemeriksaan yang rendah dan tinggi tidak jauh dari rentang normal.

Gambaran hasil pemeriksaan indeks eritrosit berdasarkan karakteristik responden dapat dilihat pada Tabel 2. Hasil rata-rata pemeriksaan indeks eritrosit berdasarkan jenis kelamin, usia, konsumsi alkohol, aktifitas merokok, dan lama bekerja menunjukan hasil normositik normokromik. Hasil nilai indeks eritrosit berdasarkan berbagai karakteristik pada responden tidak ditemukan kelainan ukuran dan warna pada eritrosit, hal tersebut kemungkinan disebabkan karena responden berada pada usia produktif, sehingga aktifitas hematopoesis (pembentukan sel darah) masih sangat aktif. Sebagian besar responden bekerja kurang dari 5 tahun sehingga paparan asap kendaraan yang setiap hari terhirup belum mampu menunjukan kelainan pada sel eritrosit.

Nilai MCV meningkat apabila eritrosit lebih besar dari biasanya (makrositik) seperti anemia kekurangan vitamin B12 dan menurun apabila eritrosit lebih kecil (mikrositik) seperti anemia pada kekurangan zat besi. Pemeriksaan nilai MCV

Tabel 2 | Karakteristik Subjek Penelitian

Karakteristik

$\operatorname{MCV}(\mathrm{Fl}) \quad \mathrm{MCH}(\mathrm{pg}) \quad \mathrm{MCHC}(\mathrm{g} / \mathrm{dl})$

\begin{tabular}{|c|c|c|c|c|}
\hline \multicolumn{5}{|l|}{ Jenis Kelamin } \\
\hline & Laki-laki & 85,5 & 29,5 & 34,6 \\
\hline & Perempuan & 86,7 & 28,7 & 33,1 \\
\hline \multicolumn{5}{|l|}{ Usia } \\
\hline & Remaja awal (12-16 tahun) & 84,1 & 29,5 & 35,0 \\
\hline & Remaja akhir (17-25 tahun) & 86,2 & 29,6 & 34,5 \\
\hline & Dewasa awal (26-35 tahun) & 84,5 & 29,4 & 34,7 \\
\hline & Dewasa akhir (36-45 tahun) & 81,9 & 26,8 & 32,8 \\
\hline \multicolumn{5}{|l|}{ Konsumsi alkohol } \\
\hline & Ya & 86,3 & 30,0 & 35,1 \\
\hline & Tidak & 85,1 & 29,1 & 34,2 \\
\hline \multicolumn{5}{|l|}{ Konsumsi rokok } \\
\hline & $\mathrm{Ya}$ & 85,6 & 29,6 & 34,7 \\
\hline & Tidak & 85,7 & 29,0 & 33,8 \\
\hline \multicolumn{5}{|l|}{ Lama Bekerja } \\
\hline & $>5$ tahun & 87,9 & 29,8 & 34,2 \\
\hline & 1-5 tahun & 84,6 & 29,2 & 34,7 \\
\hline & $<1$ tahun & 86,1 & 29,3 & 34,2 \\
\hline & Tidak menentu & 86,8 & 30,1 & 34,7 \\
\hline
\end{tabular}


mengindikasikan ukuran eritrosit berukuran kecil (mikrositik) jika nilai MCV $<80 \mathrm{fl}$, normal (normositik) jika nilai MCV 80-97 fl atau besar (makositik) jika nilai $\mathrm{MCV}>97 \mathrm{fl}$. Nilai $\mathrm{MCH}$ merupakan jumlah rata-rata hemoglobin dalam eritrosit yang dinyatakan dalam pikogram (pg). Eritrosit yang berukuran lebih besar (makrositik) cenderung memiliki nilai $\mathrm{MCH}$ yang lebih tinggi (>32 pg), sebaliknya eritrosit yang berukuran lebih kecil (mikrositik) memiliki nilai $\mathrm{MCH}$ yang lebih rendah $(<26 \mathrm{pg})$. Nilai $\mathrm{MCHC}$ yang menurun (hipokrom) jika nilai MCHC $<31,5 \%$ dijumpai pada anemia kekurangan zat besi dan thalasemia, sedangkan nilai $\mathrm{MCHC}$ yang meningkat (hiperkrom) jika nilai $\mathrm{MCHC}>34,0 \%$ dijumpai pada luka bakar dan sferositosis bawaan [7].

\section{Kesimpulan}

Berdasarkan penelitian yang dilakukan dapat ditarik kesimpulan tidak terdapat kelainan indeks eritrosit (ukuran dan warna eritrosit) pada anak jalanan di Kota Yogyakarta

\section{Apresiasi}

Penulis mengucapkan terimakasih kepada KEMENRISTEK DIKTI yang telah memberikan dana untuk penelitian ini melalui hibah penelitian dosen.

\section{Bibliografi}

1. Naour N, Fellahi S, Renucci J, Poitou C, Rouault C, Basdevant A, Dutour A, Alessi M, Bastard J, Clément K, Millo M. 2009. Potential Contribution of Adipose Tissue to Elevated Serum Cystatin C in Human Obesity. Obesity : 17 (12).

2. Lubis B, Rosdiana N, Nafianti S, Rasyianti O,Panjaitan FM. 2013. Hubungan Keracunan Timbal dengan Anemia Defisiensi Besi pada Anak. CDK-200 : vol. 40 (1).

3. Markowitz M. 2010. Lead Poisoning. In: Behrman RE, Kliegman RM, Jenson HB, editors. Nelson textbook of Pediatrics. 18th edition. Philadelphia: Saunders.p.29137.

4. Shah F, Kazi TG, Afridi HI, Baig JA, Khan S. 2010. Environmental exposure of lead and iron deficit anemia in children age range 1-5 years: A cross sectional study. Science of the Total Environmental : 5325 (30).

5. Sofro A.S.M. 2012. Darah. Pustaka Pelajar, Yogyakarta: 12-13.

6. Handayani W \& Haribowo A S, 2012. Asuhan
Keperawatan pada Klien dengan Gangguan Sistem Hematologi. Salemba Medika. Jakarta: hal. 37-39, 43, 54,59 .

7. Direktur Bina Kefarmasian, 2011. Pedoman Interpretasi Data Klinik. Kementrian Kesehatan Republik Indonesia. Jakarta. 